\title{
Health, Well-being and Wellness: An anthropological ECO-SYSTEMIC APPROACH
}

\section{Authors:}

Tiaan G.J.C. Kirsten ${ }^{1}$ Hannes J.L. van der Walt ${ }^{1}$ Charles T. Viljoen ${ }^{1}$

\section{Affiliations:}

${ }^{1}$ School of Education, North-West University, South Africa

\section{Correspondence to:}

Tiaan Kirsten

e-mail:

tiaan.kirsten@nwu.ac.za

\section{Postal address:}

Internal Box 34, NorthWest University, Private Bag X 6001, Potchefstroom, 2521, South Africa

\section{Keywords:}

wellness; holistic; unitas complex; biomedical model; Capra

\section{Dates:}

Received: 07 May 2008

Accepted: 21 Oct. 2008

Published: 24 Apr. 2009

How to cite this article: Kirsten, T.G.J.C., Van der Walt, H.J.L. \& Viljoen, C.T., 2009, 'Health, wellbeing and wellness: An anthropological eco-systemic approach', Health SA Gesondheid 14(1), Art. \#407, 7 pages. DOI: 10.4102/hsag.v14i1.407

\section{This article is available} at:

http://www.hsag.co.za (c) 2009. The Authors. Licensee: OpenJournals Publishing. This work is licensed under the Creative Commons Attribution License.

\section{ABSTRACT}

More than two decades ago, Fritjof Capra commended - and indeed advocated - a paradigm shift in health science and care. In his book The Turning Point (1982) he talks of a major shift from the preoccupation with micro-organisms to a careful study of the 'host organism and its environment', of 'significant attempts to develop a unified approach to the mind/body system' in Western medicine, of 'a new holistic paradigm' (as opposed to 'the old biomedical paradigm') regarding the problem of health and healing, of 'a holistic and humanistic approach to primary care', and of 'a holistic therapy' as opposed to 'the traditional biochemical practice of associating a physical disease with a specific physical cause'. Our concern in this article is with the paradigm shift advocated by Capra in this book and the progress that has since been made.

\section{OPSOMMING}

Meer as twee dekades gelede het Fritjof Capra 'n pleidooi gelewer vir ' $n$ paradigmaskuif vanaf die biomediese model na ' $n$ meer holistiese, ekosistemiese model van gesondheid en genesing. Die vraag wat in hierdie artikel aan die orde kom is of praktisyns in die veld van die gesondheidswetenskappe sedertdien daarin geslaag het om die oorgang na die aanbevole paradigma te maak. 'n Oorsig van die literatuur sedert 1982 toon dat die skuif nog nie regtig gemaak is nie. 'n Ander literatuuroorsig toon voorts dat die terme 'gesondheid', 'well-being' en 'wellness' as uitruilbaar beskou word en dat hulle betekenisse meermale afhang van die gebruikskonteks. Op grond van hulle bespreking van die antropologiese ekosistemiese benadering tot gesondheid en genesing stel die outeurs voor dat die terme 'gesondheid' en 'wellness' as korrelatiewe gebruik word, en dat die term 'well-being' gebruik word vir al die domeine van menslike leween bestaan watkan bydra tot gesondheid, oftewel 'wellness'.

\section{INTRODUCTION}

\section{The problem}

The value of the Hippocratic theory about the treatment of disease was that it oriented medicine toward a biological approach and away from superstition (Rohman 2002:180). The history of modern medicine has its roots in the practices and theories of the followers of Hippocrates: they started a presumption that has gained ground ever since, namely that nothing needs to be explained in divine terms. The physical world is all there is (Armesto 2004:135). At the core of Hippocratic medicine is the conviction that medicine should be practised as a scientific discipline, based on the natural sciences and aimed at the prevention of illnesses, as well as their diagnoses and therapy. This attitude, says Capra (1982:340), has formed the basis of scientific medicine 'to the present day' (i.e. 1982).

According to Capra (1982:340), Hippocratic theory also accounted for ecological factors, but this aspect has been neglected with the rise of Cartesian (rationalistic) science. One of the books in the Hippocratic Corpus, entitled Airs, Waters and Places, represents what we would today call a treatise on human ecology. It shows, in detail, how the well-being of individuals is influenced by environmental factors such as the quality of air, water and food, the topography of the land and general living habits. The correlation between sudden changes in these factors and the disappearance of disease is emphasised, and the understanding of environmental effects is seen as the essential basis of the physician's art. As Capra writes:

the Hippocratic tradition, with its emphasis on the fundamental interrelation of body, mind, and environment, represents a high point in Western medical philosophy that is as strong in its appeal for our time as it was twenty-five hundred years ago.

(Capra 1982:341)

Capra (1982:336) also concluded, however, that Western medical practitioners, in following the biomedical model, seem to have lost this holistic view of health and healing. A Western doctor asked about the causes of illness, he says, will talk about bacteria and physiological disorders. In Western medicine, the doctor with the highest reputation is a specialist who has detailed knowledge about only a specific part of the body (Capra 1982:346). In 1982, he says, most practitioners made no practical attempt to deal with the psychological and social aspects of illness therapeutically (Capra 1982:348; also see Jordaan \& Jordaan 2000:227). In other words, Capra (1982:337-338) concludes, modern Western medicine (in 1982) was not consistent with a systems view of nature and the conception of illness as a consequence of disharmony and imbalance, which play a central role in the 'new' holistic approach.

The question facing us now, more than two decades after Capra wrote these words, is whether the field of the health sciences has progressed in terms of making the paradigm shift from a biomedical approach to health, well-being and wellness to what we prefer to call an eco-systemic anthropological perspective, especially with respect to the meaning of the constructs health, well-being and wellness. 


\section{Methodology}

To find an answer to this question, we report on a literature survey to establish how health, well-being and wellness have been approached in post-1982 publications. We then discuss health, well-being and wellness from an eco-systemic anthropological perspective. We conclude by making some suggestions about the use of the terms 'health', 'well-being' and 'wellness' in terms of this holistic paradigm. At a deeper philosophical level, our approach was constructivist-interpretive in that we constructed and interpreted reality. We also followed what had been provocatively called transcendental pragmatism by Alexander (2006:206): “We brought our own conception of what it might mean to solve the problem at hand".

\section{Health, well-being and wellness in post-1982 publications}

The New Oxford Dictionary of English (1998:864) still provides us with a biomedical and mechanistic 'definition' of health. It sees 'health' pithily as 'the state of being free from illness or injury'. This 'definition' seems more concerned with the absence of certain conditions than the presence of others. It also does not mention the notions of well-being and wellness. Philosophically, this view resonates with psychological egocentrism: the world is comprehended only from a personal or subjective point of view, which implies a failure to differentiate subjective from objective acts of experience (Colman 2003:233). All action is in effect selfinterested, self-absorbed and competitive (Mautner 2000:160; Baron, Byrne \& Branscombe 2006: 398).

The Collins Concise Dictionary (Sinclair 1999:662) offers a relativist-functionalist perspective. It expands the meaning of 'health' somewhat by stating that health is the state of being bodily and mentally vigorous and free from disease (also see Boddy 1989:487; Dewsbury 1991:198 et seq.; Campbell et al. 2000; Kickbusch \& Payne 2003; Bambra, Fox \& Scott-Samuel 2005; MacClanahan, Huff \& Omar 2006). The Oxford Advanced Learner's Dictionary (Wehmeier 2002:551) resonates with both a relativist-functionalist and a homocentric view in that it defines health as the condition of a person's body or mind, the state of being physically and mentally healthy, and able to function optimally within all of these dimensions. Its definition is based on the conviction that the well-being of people and the living systems of the planet which they inhabit come first (Van Vlaenderen \& Neves 2004:9-3)

The Cambridge International Dictionary of English (Procter 2002:655) provides us with an 'idealistic' perspective on health, one which philosophically seems to resonate with an eco-centric paradigm, i.e. the assumption that all things in nature are related to one another in a complex but systematic way (Meyer, Moore \& Viljoen 2003:464). It broadens the meaning of health by also using the term 'well-being' in its definition: the condition of the body and the degree to which it is free from illness, or the state of being well. Although the often quoted World Health Organization's (WHO) (1999) definition of health is also somewhat broader, it is still not adequate in terms of the eco-systemic perspective on which we expound later in this article. The WHO defines 'health' as 'a state of complete physical, mental, and social wellbeing and not merely the absence of disease or infirmity'. This definition is not entirely satisfactory, in that the 'complete state' it refers to does not include, for instance, the spiritual dimension of human life (see Myers, Sweeney \& Witmer 2000). Although well-being is included (making it better than the other definitions mentioned above), it is not quite clear what well-being entails. We will return to this problem in our more detailed discussion of the concepts 'health', 'well-being' and 'wellness'. (Note that we place concepts in inverted commas when we refer to them).

According to Kriel (1998:8-9) and Wass (2000:46), even the somewhat broader definition offered by the WHO still tends to be largely ignored in favour of a bio-medical focus on the physical health of individuals only. This can be ascribed inter alia to the influence of the colloquial use of the term 'health'.

In all of these narrow(er) conceptions of health, health and disease are viewed as the extremes on a continuum: the presence of the one implies the absence of the other. In the bio-medical model, a person is deemed healthy when medical care is no longer required. A disease-free population is therefore a healthy one, and vice versa (see Edelman \& Mandle 1994:8-9; Parmer \& Rogers 1997:1). For the most part, health is taken as pertaining to the physical body only. The use of the term 'mental health' would have been unnecessary if health were seen to pertain to more aspects of a person than only the physical body (cf. Ryff \& Singer 1998:1). Because of such 'medicalised' or 'physicalised' concepts of health, educators and educationists, for instance, have been led to think that schools are for teaching-learning only, and that health promotion falls outside their ambit. The same applies to the division of tasks between state departments: because health promotion is seen as the responsibility of the Department of Health only, other departments, such as Industry or Public Works, (are expected to) refrain from attending to health matters. According to Schriven and Orme (1996:22), this tendency can be ascribed to a lack of insight into the logic of and need for inter-sectoral collaboration.

Despite the broader definition of health of the WHO and in the Ottawa Charter for Health Promotion (November 1986), the Jakarta Declaration on Health Promotion (July 1997) and the South African national objectives for health promotion (2000), and understanding that the term 'health' has to refer to much more than only a desired biophysical condition or the absence of disease in people, very little progress has been made in practice in terms of these broader ideals and policies, says Wissing (2000:5). Kriel (1998:8-9) agrees with her in stating that some health practitioners still use a mechanistic medical model.

In Hull's opinion (2005:550-551), on the other hand, it is difficult to eradicate all mechanistic theories. Mechanism in extreme forms is clearly false, but working with weaker forms seems unavoidable. For instance, meiosis cannot readily be explained without reference to the underlying 'mechanistic' processes.

This brief discussion shows that, according to the post-1982 literature, a complete turn towards a more holistic view of health, well-being and wellness has not yet been made. Much of what Capra observed about health and healing back in 1982 is still applicable today. The literature review confirmed that, even today and despite growing understanding of the importance of the wholeness of the human being, practitioners in the field of health science are in need of clearer insight into how the notions or objectives of health, well-being and wellness tie in with each other in terms of an eco-systemic anthropology.

\section{Eco-systemic anthropology and the health of human beings}

The eco-systemic approach to health, well-being and wellness is based on two assumptions. The first is that the human being is a whole, a complete person of whom certain attributes can be distinguished but never separated. This anthropology does not allow the health, well-being and wellness of a person to be attributed to only the absence of disease in the mind or the physical body. The human being is a totality, a complete whole. The South African Department of Health (2000:16) seems to share this assumption by insisting on 'the creation of effective teaching and learning through the holistic development of the school and other sites'. The second assumption flows from the first, viz. that when we contemplate the health, well-being and wellness of a person, we should approach the matter multi-dimensionally as well as multi-disciplinarily.

These two assumptions agree with the 20th century realisation that mind and body are not as separable as previously thought. This new realisation gave birth to new conceptualisations, such 


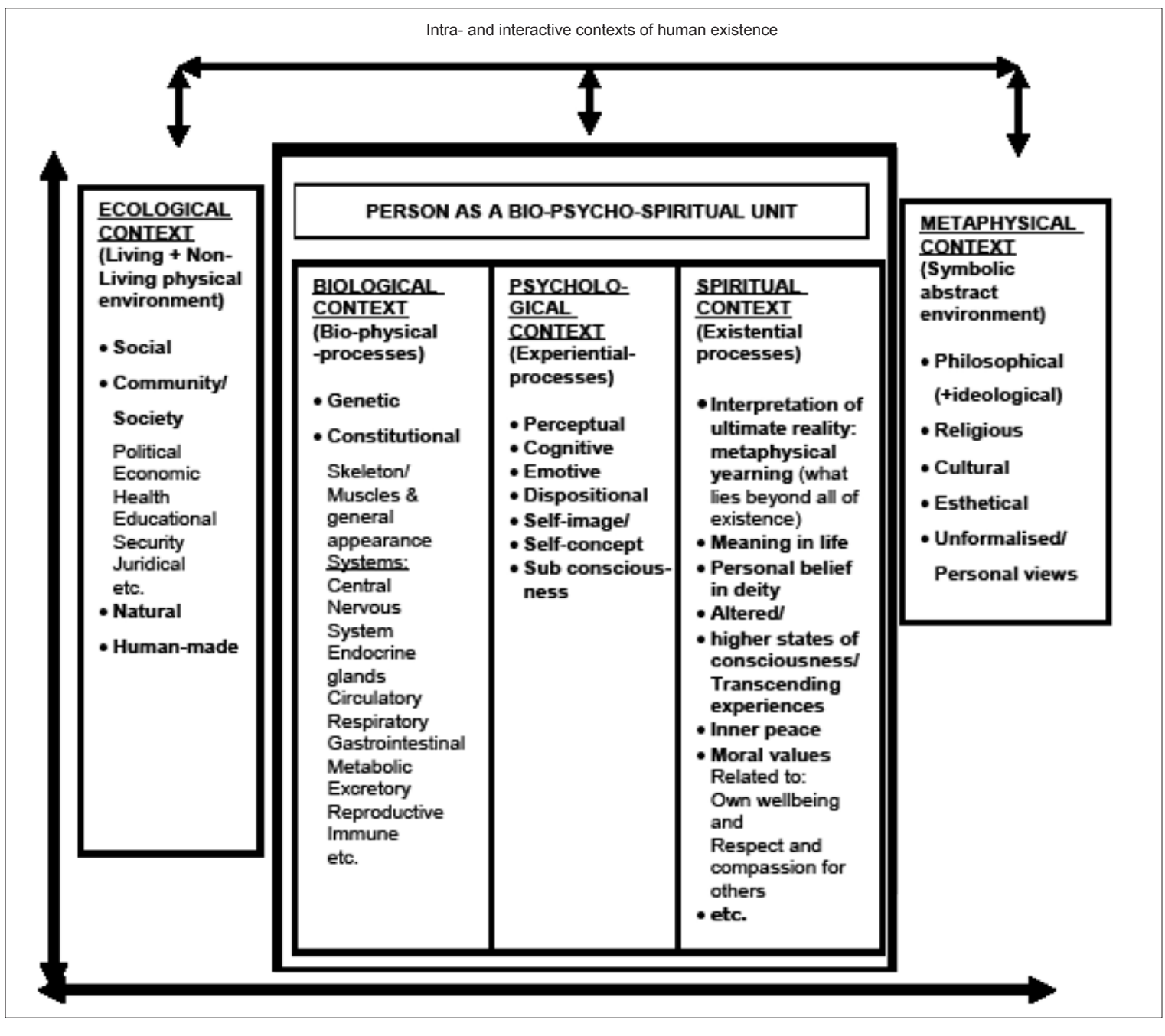

FIGURE 1

A holistic eco-systemic view of the health, well-being and wellness of the human being

as 'psychobiology' (Dewsbury 1991:198-203), and, after factoring in other ecological aspects (Dewsbury 1991:199), Engel's holistic bio-psychosocial model (Boddy 1989:487; Jordaan \& Jordaan 2000:554; Colman 2003:92). According to Vollhardt (1991:35-36), this model can help us explore the interactions between social, psychological and biological factors; a person's general state of health is always the outcome of an interplay between bio-, psycho- and socio-processes (Jordaan \& Jordaan 2000:227).

Gordon (1990:358), however, conceptualises that a biopsychosocial model does not go far enough. A holistic model should also include a fourth dimension, viz. the spiritual, because it enlarges and encompasses the domain of the bio-psychosocial (also see Valenkamp \& Van der Walt 2006:11-15). For the model to resonate well with the anthropological assumptions that we formulated above, it should be expanded even further, as can be illustrated by referring to the model presented by Jordaan and Jordaan $(1990 ; 1998)$ and developed further by Kirsten (1994; 2001; 2004) (see Figure 1).

In Figure 1, the middle three sets of elements, contexts or domains describe the functioning of a totally integrated person. They are the constitutive elements of a living person as a bio-psychospiritual being. The two outside contexts describe the total living and non-living physical realities, as well as the symbolic or abstract realities in which the person finds himself or herself; in other words, the interpersonal element of human interaction or the external environment. Although the five sets of contexts are distinguishable, they remain inseparable. It would be impossible for a person to live without being a bio-psycho-spiritual being. Losing one of the contexts or separating one from the others would mean death, or at the most a vegetative existence. Existence without some or other environment is inconceivable. All the contexts or domains are holistically involved in the life of the human being, and they are in constant intra- and interaction. Failure on the part of an individual to relate appropriately to any of these contexts will be detrimental to his or her health, wellbeing and wellness.

With certain adaptations, Papp's comments (as reported in Plas 1986:47) on the holistic systems theory can be applied to the holistic eco-systemic model outlined in Figure 1. The central ideas of this theory are that the whole is considered to be greater than the sum of its constitutive parts; each can only be understood in the context of the whole. A change in any part will affect every other part, and the whole regulates itself through a series of feedback loops. Feedback loops travel back and forth within the system in order to provide stability, equilibrium and homeostasis for the person as a living being. The constitutive parts are constantly changing in order to keep the person as a living human being balanced.

A change in any of the constitutive elements or domains of the living person will affect every other aspect, element or domain. The holistic eco-systemic model represents a clear departure from a mechanistic medical-disease model according to which 


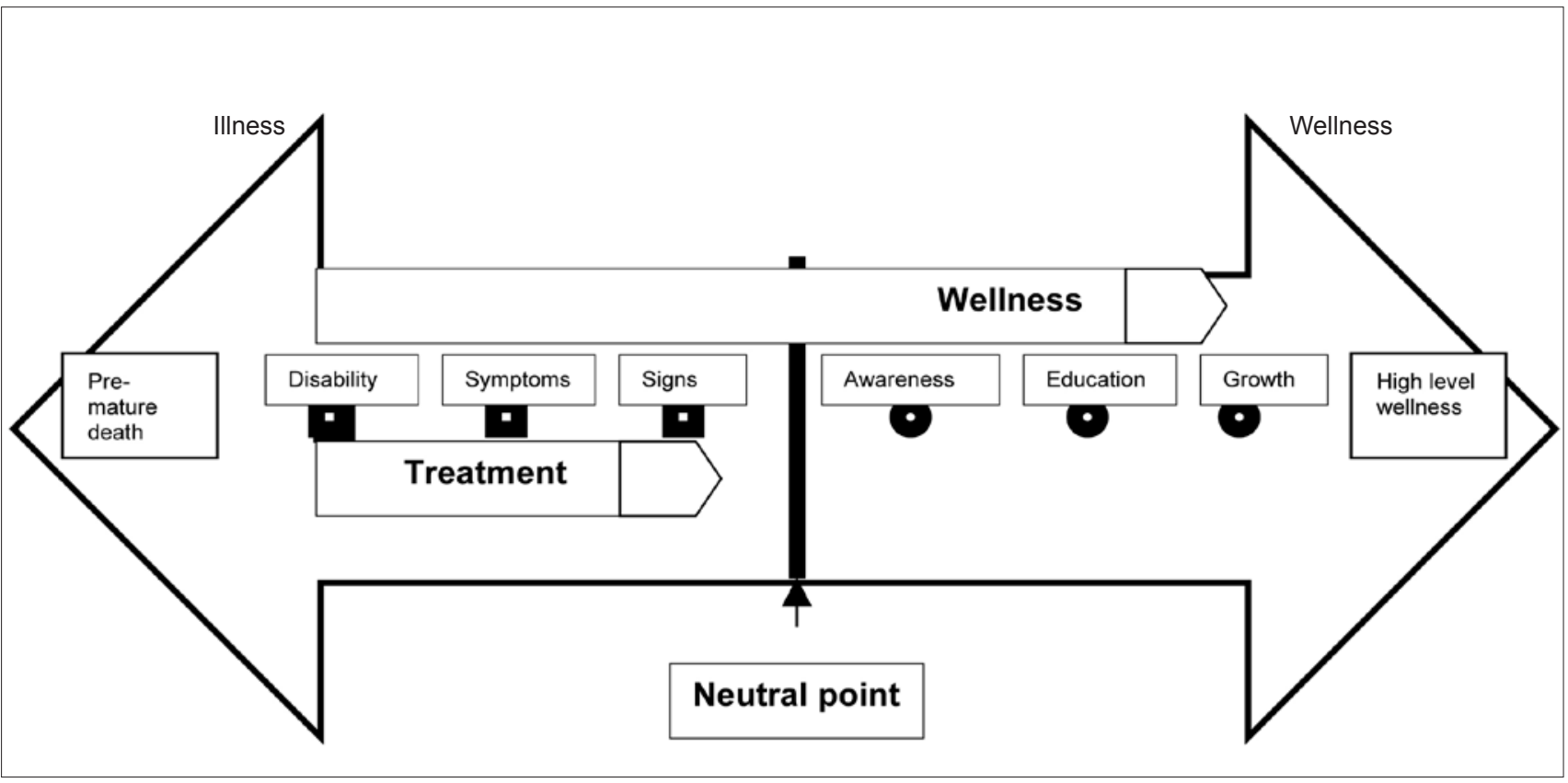

FIGURE 2

disease is seen as a problem only in the person, and where the total environment in which he or she lives is not taken into account. It goes beyond the study of biological mechanisms and tries to discover the causes of illness in environmental influences, psychological patterns and social relations (Capra 1982:338). A truly holistic approach, Capra (1982:351) insists, recognises that the environment created by the Western social and economic system, based on the fragmented and reductionist (rationalistic) Cartesian world view, has become a major threat to people's health. An ecological approach to health, wellbeing and wellness will therefore make sense only if it leads to profound changes in Western technology and Western social and economic structures, as indicated below.

The holistic view of health, well-being and wellness (Figure 1) is an improvement on the WHO view in that it also recognises the spiritual dimension of the human being, as well as the fact that the environment of human beings consists of both living and non-living elements or domains. It recognises that the environment does not exist of only a social environment, as suggested in the $\mathrm{WHO}$ view, or only a social, economic and technical environment, as suggested by Capra, but also of a natural-physical environment, a human-made physical environment, other living creatures and a metaphysical and/ or transcendental dimension, all of which link up with an ecosystemic view. This model reflects a view of the environment as a total ecological context and not as a social context only. It also includes a metaphysical context consisting of a whole range of symbolical environments such as philosophy (personal life view), ideology, religion and culture. A person, together with his or her health, forms an environmental context that can influence other people, and vice versa.

For a particular individual to be healthy and feel well, and to enjoy a good quality of life, as many as possible of the people around him or her should also be healthy and well. If a person's environment, in terms of other people and their contexts, is not healthy, his or her health/wellness can be affected adversely. This aspect of an eco-systemic approach reflects the interactive element of the internal and external environments of human existence. Health, well-being and wellness are brought on by a fine balance between these two environments. A downward spiralling of undesired contextual conditions can be detrimental to the actualising of the person's potential, and to his or her health (cf. Ewart 1991:940). A person's bio-psycho-spiritual health is inextricably linked to the state of the health of his or her physical and symbolic environment. This is observable in the compromised health of a person living in a malaria-stricken area in Africa, or in an HIV / AIDS-ridden community. Health clearly cannot be approached as a personal and biological issue or state only (cf. Prilleltensky \& Nelson 2002:8-2; 93-94; 108-12).

By the same token, good or optimal health can be observed in persons able to enjoy a good quality of life in all the contexts of their existence, and who are able to actualise their potential. Health promotion, then, should be approached in terms of helping people to use the potential of all their contexts as possible contributors to their health (Kirsten 1994:219; Kirsten \& Viljoen 2001; Kirsten \& Viljoen 2003; Kirsten 2004; Wass 2000:47).

The dynamic nature of health, well-being and wellness In the eco-systemic model (Figure 1), the vertical line on the left and the horizontal line at the bottom indicate that holistic health/wellness is a continuous and dynamic process (cf. Myers et al. 2000:251). The attainment of health/well-being/wellness is a life-long process, something of which health practitioners never should lose sight. This is graphically illustrated in Figure 2 (also see Edelman \& Mandle 1994:14; Kirsten 1994:131).

If a person should experience some form of disability or disease or has not yet sufficiently taken responsibility for his/her own and others' health/well-being/wellness, a form of illness surfaces (defined in terms of the eco-systemic anthropology as unwellness, i.e. not as a biomedical term but as a state-of-being term) and a need for promoting wellness arises. Illness in this context has social and psychological, as well as biomedical and spiritual ramifications; for example, a person can have a disease without feeling ill, such as asymptomatic hypertension or HIV (Edelman \& Mandle 1994:14; Jensen \& Allen 1994:6). The promotion of wellness is directed at more than the mere attainment of a neutral or symptomless (biomedical) state; it strives for the attainment of the highest possible level of functioning in all aspects (or domains/components/contexts of well-being) of human existence. Health/well-being/wellness can be promoted regardless of the particular point on the illnesswellness continuum at which a particular person might find himself or herself. 
The concepts 'health', 'well-being' and 'wellness' from an eco-systemic perspective

Our literature survey indicated that 'health', 'well-being' and 'wellness' tend to be used interchangeably, much as we have done so far in this discussion. Green and Shellenberger (1991:15, 18-19) use the combined term 'health and wellness' for their holistic orientation (with 'health' referring to an objective biomedical condition and 'wellness' to a more emotional condition, i.e. feeling well or unwell). Wass (2000:47), in turn, points out that many people may identify themselves as healthy more by a sense of well-being than by the absence of disease. The WHO (1986; 1995) and the South African Department of Health (2000) use the terms 'health' and 'well-being' repeatedly, but not 'wellness'. Wissing (2000:5), on the other hand, says that 'health' and 'wellness' have similar denotations and connotations and can be used interchangeably (although the meanings might differ depending on the context). Van Eeden (1996:9) makes similar claims with respect to 'health', 'well-being' and 'wellness' in a psychological context. Quite recently, Walsh (2005:955) remarked that well-being has been variously interpreted as 'living and faring well' or 'flourishing', and that the notion of well-being is intricately bound up with our ideas of what constitutes human happiness and the sort of life that is good to lead (a notion that frequently surfaces in so-called happiness and quality-of-life studies, cf. Veenhoven 2000, 2002, 2008; a point also made by Aristotle and Oriental philosophers such as Confucius). McPherson (2001), Caras (2003) and Lewis, Maltby and Day (2005) all subscribe to this view: they see a connection between the (subjective) well-being of a person and, in this case, the spiritual dimension of being human. According to Olivier, De Jager, Grootboom and Tokota (2005:914), wellness 'can be described as a conscious process of holistic self-development, based on personally determined goals for wellbeing', leading among others to community health and well-being.

'Wellness' is often used as a sales gimmick (Fahlberg \& Falhlberg 1997:1; Seligman \& Csikszentmihalyi 2000:7) in the titles of popular books dealing, for instance, with the symptomatic relief of hypertension and with weight reduction for the purpose of achieving an 'average state of health' (Pelletier 1988:9). The same tendency is also observable in academic circles. 'Wellness programs,' say Watt, Verma and Flynn (1998:2), 'are usually aimed at patients with chronic illnesses.'

Our literature review did not reveal consistent patterns of and conceptual links between the meanings of 'health', 'wellbeing' and 'wellness'. All of them are occasionally used in a reductionistic sense, for instance referring only to physical conditions, or to a certain domain of human life and existence. All of them have been applied to express ideas flowing from a holistic anthropology, and all of them have also been used to express the interconnectedness between various aspects of human existence and the interaction between the internal and external environments of human existence. We have to conclude, therefore, that these three terms have indeed been used interchangeably. The meaning of a particular term has to be derived from the context in which it is used.

We would suggest, however, that in terms of the eco-systemic view, we should distinguish as follows between the meanings of the three concepts:

- Well-being refers to the condition of specific aspects or domains of health/wellness (see bulleted paragraph below and Figure 1), such as the physical, the psychosocial or the social (Grzywacs 1999:1, 5; Hermon \& Hazler 1999:1; Wissing 2000:8-9). Domains of well-being can be regarded as facets of holistic wellness and health (cf. Parmer \& Rogers 1997:1; Hermon \& Hazler 1999:2, 4; Wissing 2000:9, 13). The different domains of well-being focus on the whole person and therefore pertain to more than the physical body. Amongst other things, it also includes the mind, spirit, emotions, meaning, behaviour, social relationships - and an inherent interconnectedness of the person with the environment (Schafer 1996:33; Greenburg \& Dintiman 1997:2-3). Figure 1 shows that 'well-being' can be used for referring to all the different contexts, constitutive elements or parts, or domains of human existence. Well-being is not purely descriptive, however. To refer to someone as 'well' is also a commendation. Like health/wellness, wellbeing carries with it a positive valuation, but also offers a description of that to which it is applied. Because the constitutive elements of well-being are the building blocks of health/wellness, the promotion of well-being in each of them will ultimately lead to a state of health/wellness in the person (Hofford \& Spelman 1996:3). In a sense, the wellbeing of a domain of existence can be regarded as a means to an end (in the same way that the health of a person can be a means to the end of happiness).

- Wellness serves as an umbrella term, a unitas complex for the optimal well-being of the different domains (cf. Seeman 1989:1102). It can be defined as the proper harmony and balance resulting from promoting the well-being of all the different facets, constitutive elements or domains of existence of a person (Garrett 1999:4). The well-being of the different domains mentioned in the previous bulleted paragraph serves as a means to the end of happiness. To attain a state of wellness, harmony and balance should be reached with respect to all the relationships between mind, body and spirit, as well as the natural, social and cultural environments. Wellness is 'a whole of life' view (Wass 2000:46; also see Uys 1992:150, 155, 157) or what Maslow referred to as 'the farther reaches of human nature' derived from the integration and interrelatedness of the various domains of well-being (Parmer \& Rogers 1997:1).

- If health is understood to refer to the state of optimal functioning of a human being, a state of enjoying a good quality of life and experiencing a feeling of complete equilibrium - both as a result of having succeeded in optimising the potential in the total living environment, there is no essential difference between wellness and health (which explains why we use health/wellness as correlatives). The absence of disease and/or weakness is only one of a multitude of personal and environmental conditions that have to be met for a person to truly be and feel healthy/well. Health or wellness in this sense is a uniquely personal and subjective experience about which each person has his or her own narrative. Even if defined in universal, academic terms, as we have attempted to do here, it can never adequately describe the state of health / wellness experienced by a particular person (also see The American Holistic Medical Association in Anderson 1987:6; Anderson 1987:6; Elsenrath, Hettler \& Leafgren 1988:1; Light 1995:2; Schafer 1996:33, 37; Fahlberg \& Fahlberg 1997:2; Greenburg \& Dintiman 1997:2-3; Watt et al. 1998:2; Hermon \& Hazler, 1999:1-2; Adams \& Bezner, 2000:2; Myers et al. 2000:252; Kirsten 2001; Kirsten 1994:210; Westgate 1996:1; Wissing 2000:9; Myers et al. 2000:252).

\section{RECOMMENDATION AND CONCLUDING REMARK}

Health practitioners and scholars should no longer view health/ wellness from the traditional bio-medical or mechanisticsystemic point of view. As Capra advocated in 1982, better anthropological insight compels us to look at health/wellness from a broader perspective, such as the eco-systemic model. This model accentuates not only the holistic unitas complex nature of health/wellness, but also that the promotion of health/wellness is a life-long process.

We found no essential distinction between health and wellness in the eco-systemic sense, but recommend the use of 'wellness' as a way of avoiding the traditionally restricted meaning of 'health' as the absence of disease. Health practitioners who still 
prefer to use the term 'health' are challenged to qualify their use of it, i.e. as not referring to the absence of disease, but rather holistically to a human state of being. Practitioners who prefer the use of 'wellness', on the other hand, should indicate that they do not understand wellness as the opposite of illness in the traditional bio-medical sense, but rather in the context of a holistic anthropology, i.e. as a human state of being. The term 'well-being', on the other hand, should be reserved for referring to the functioning of the different domains or contexts of a person's life, the promotion of all of which promotes the health/ wellness of the person.

\section{REFERENCES}

Adams, T.B. \& Bezner, J.R., 2000, 'Conceptualization and measurement of the spiritual and psychological dimensions of wellness in a college population', Journal of American College Health 48(4), 165.

Alexander, H., 2006, 'A view from somewhere: Explaining the paradigms of educational research', Journal of Philosophy of Education 40(2), 205-221.

Anderson, R.A., 1987, Wellness medicine: A guide and handbook to collaborative health care, Keats Publishing, New Canaan.

Armesto, F.F., 2004, Ideas that changed the world, Dorling Kindersley, London.

Bambra, C., Fox, D. \& Scott-Samuel, A., 2005, 'Towards a politic of health', Health Promotion International 20(2), 187-193.

Baron, R.A., Byrne, D. \& Branscombe N.R., 2006, Social psychology, Pearson, Boston.

Boddy, J., 1989, 'The benefits of physiological psychology', British Journal of Psychology 80, 479-489.

Procter, P. (ed.), 2002, Cambridge international dictionary of English, Cambridge University Press, Cambridge.

Campbell, M., Fitzpatrick, R., Haines, A., Kinmonth, A.L., Sandercock, P., Spiegelhalter, D. \& Tyrer, P., 2000, 'Framework for design and evaluation of complex interventions to improve health', British Medical Journal 321, 694-696.

Capra, F., 1982, The Turning Point, Fontana/Flamingo, London.

Caras, C., 2003, 'Religiosity/spirituality, and subjective wellbeing', BA (Hons) dissertation, Deakin University.

Colman, A.M., 2003, A dictionary of psychology, Oxford University Press, Oxford.

Dewsbury, D.A., 1991, 'Psychobiology', American Psychologist 46(3), 198-205.

Edelman, C.L. \& Mandle, C.L., (eds.), 1994, Health promotion throughout the lifespan, Mosby, St Louis.

Elsenrath, D., Hettler, B. \& Leafgren, F., 1988, Lifestyle assessment questionnaire, 15th edn., Steven Point University, Wisconsin.

Ewart, C.K., 1991, 'Social action theory for a public health psychology', American Psychologist 46(9), 931-946.

Fahlberg, L.L. \& Fahlberg, L.A., 1997, 'Wellness re-examined: A cross-cultural perspective', American Journal of Health Studies 13(1), 8, 9, viewed 1 March 2001, from http://www-sa.ebsco. com.

Garrett, M.T., 1999, 'Soaring on the wings of an eagle: Wellness of native American high school students', Professional School Counselling 3(1), 57, viewed 1 March 2001, from http://wwwsa.ebsco.com.

Gordon, J.S., 1990, 'Holistic medicine and mental health practise: Toward a new synthesis', American Journal of Orthopsychiatry 60(3), 357-369.

Green, J. \& Shellenberger, R., 1991, The dynamics of health and wellness: A biopsychosocial approach, Holt, Rinehart \& Winston, Chicago.

Greenburg, J.S. \& Dintiman, G.B., 1997, Wellness. Creating a life of health and fitness, Allyn and Bacon, Boston.

Grzywacz, J.G., 1999, 'Growing up healthy: The ecology of child well-being', Family Relations 48(4), 433, viewed 1 March 2001, from http://www-sa.ebsco.com.

Hermon, D.A. \& Hazler, R.J., 1999, 'Adherence to a wellness model and perceptions of psychological well-being', Journal of Counselling and Development 77(3), 339, viewed 1 March 2001, from http://www-sa.ebsco.com.
Hofford, C.W. \& Spelman, K.A., 1996, 'The community action plan: Incorporating health promotion and wellness into alcohol, tobacco and other drug abuse prevention efforts on the college campus', Journal of Wellness Perspectives 12(2), 70, viewed 1 March 2001, from http://www-sa.ebsco.com.

Hull, D.L., 2005, 'Mechanistic explanation', in R. Audi (ed.), The Cambridge dictionary of philosophy, 2nd edn., pp. 550-551, Cambridge University Press, Cambridge.

Jensen, L.A. \& Allen, M.N., 1994, 'A synthesis of qualitative research on wellness - illness', Qualitative Health Research 4(4), 349, viewed 1 March 2001, from http://www-sa.ebsco. com.

Jordaan, W. \& Jordaan, J., 1990, Mens in konteks, 2de uitgawe, Lexikon, Isando.

Jordaan, W. \& Jordaan, J., 1998, People in context, 3rd edn., Heinemann, Johannesburg.

Kickbusch, I. \& Payne, L., 2003, '21st century health promotion: The public health revolution meets the wellness revolution', Health Promotion International 18, 275-278.

Kirsten, G.J.C., 1994, 'Die bevordering van geestesgesondheid as opvoedkundige sielkundige opgawe', MEd dissertation, Universiteit van Pretoria.

Kirsten, G.J.C., 2001, 'The use of meditation as a strategy for stress management and the promotion of wellness in teachers: An educational psychological study', $\mathrm{PhD}$ thesis, Potchefstroom University for Christian Higher Education.

Kirsten, G.J.C., 2004, 'Out of Africa: Exploratory thoughts in weaving the beginnings of a wellness counselling and therapy model', poster presented at the 2nd European Conference on Positive Psychology, Verbania Pallanza, 5-8 July.

Kirsten, G.J.C. \& Viljoen, C.T., 2001, 'Health promoting schools: The educational link to sustainable social development', in Sustainable development: Critical issues, pp. 68-78, Network Publishers, Pretoria.

Kirsten, G.J.C. \& Viljoen, C.T., 2003, 'The health of teachers: Exploratory thoughts in moving from toxic schools to health promoting schools - the case of managers with narcissistic personality disorder', paper presented at the Education Society of South Africa Conference, University of Stellenbosch, 14-16 January.

Kriel, J.R., 1998, Viagra and the mind-body problem. Philosophical implications of a pharmaceutical innovation, IRS (Series F1: 372), Potchefstroom.

Lewis, C.A., Maltby, J. \& Day, L., 2005, 'Religious orientation, religious coping and happiness among UK adults', Elsevier Personality and Individual Differences 38, 1193-1202.

Light, K.M., 1995, 'Wellness and the liberal arts: A new dimension in the care curriculum', Wellness Perspectives 11(3), 28, viewed 1 March 2001, from http://www-sa.ebsco.com.

MacClanahan, K.K., Huff, M.B. \& Omar, H.A., 2006, 'Holistic health: Does it really include mental health?', TSW Holistic Health E Medicine 3, 128-135.

Mautner, T., 2000, The Penguin dictionary of philosophy, Penguin Books, London.

McPherson, W., 2001, 'Spirituality and well-being', BA (Hons) dissertation, Deakin University.

Meyer, W., Moore, C. \& Viljoen, H., 2002, Personology: From individual to ecosystem, Heinemann, Johannesburg.

Myers, J.E., Sweeney, T.J. \& Witmer, J.M., 2000, 'The wheel of wellness counselling for wellness: A holistic model for treatment planning', Journal of Counselling and Development $78,251-266$.

Olivier, M.A.J., De Jager, M.J., Grootboom, P. \& Tokota, K.B., 2005, 'Work wellness: A prerequisite for effective education in higher education institutes', South African Journal of Higher Education 19(5), 912-930.

Parmer, T. \& Rogers, T., 1997, 'Religion and health: Holistic wellness from the perspective of two African American church denominations', Counselling and Values 42(1), 55, viewed 1 March 2001, from http://www-sa.ebsco.com.

Pelletier, K.R., 1988, 'Influence of transcendental meditation on perceptual style: Increased field independence', in D.W. 
Orme-Johnson \& J.T. Farrow (eds.), Scientific research on the Transcendental Meditation Program: Collected papers, vol. 1, pp. 337-345, Maharishi European Research University Press, New York.

Plas, J.M., 1986, Systems psychology in the schools, Pergamon, New York.

Prilleltensky, I. \& Nelson, G., 2002, Doing psychology critically. Making a difference in diverse settings, Palgrave Macmillan, New York.

Rohman, C., 2002, The dictionary of important ideas and thinkers, Arrow Books, London.

Ryff, C.D. \& Signer, B., 1998, 'The contours of positive human health', Psychological Inquiry 9(1), 1-28.

Schafer, W., 1996, Stress management for wellness, Harcourt Brace, Florida.

Schriven, A. \& Orme, J., 1996, Health promotion. Professional perspectives, Macmillan Press, London.

Seeman, J., 1989, 'Toward a model of positive health', American Psychologist 44(8), 1099-1109.

Seligman, M.E.P. \& Csikszentmihalyi, M., 2000, 'Positive psychology: An introduction', American Psychologist 55(1), 5-14.

Sinclair, J.M., (ed.), 1999, Collins concise dictionary, Collins, Glasgow.

South African Department of Health, 2000, National guidelines for the development of health promoting schools/sites in South Africa, Government Printers, Pretoria.

The New Oxford Dictionary of English, 1998, Oxford University Press, Oxford.

Uys, J., 1992, Psychological counselling in the South African context, Maskew Miller Longman, Cape Town.

Valenkamp, M. \& Van der Walt, J.L., 2006, 'The spiritual dimension of 'quality of life', with special reference to education', paper presented at the International Conference of the International Society for Quality of Life Studies (ISQOLS), Rhodes University, Grahamstown, July 17-20.

Van Eeden, C., 1996, 'Psigologiese welstand en kohesiesin', $\mathrm{PhD}$ thesis, Potchefstroom University for Christian Higher Education.

Van Vlaenderen, H. \& Neves, D., 2004, 'Activity theory as a framework for psychological research and practice in developing societies', in K. Ratele, N. Duncan, D. Hook, P. Kiguwa \& A. Collins (eds.), Self, community and psychology, 9-1 \& 9-20, University of Cape Town Press, Lansdowne.
Veenhoven, R., 2000, 'The four qualities of life: Ordering concepts and measures of the good life', Journal of Happiness Studies 1, 1-39.

Veenhoven, R., 2002, 'Het grootste geluk voor het grootste aantal. Geluk als richtsnoer voor beleid. (The greatest happiness for the greatest number of people. Happiness as a policy guideline.)', Sociale Wetenschappen 4, 1-43.

Veenhoven, R., 2008, 'Geluk is eenvoudig te meten. (Happiness is easy to measure.)', Rotterdam e.o. Metro, 18 January, p. 1419).

Vollhardt, L.T., 1991, 'Psychoneuroimmunology: A literature review', American Journal of Orthopsychiatry 61(1), 35-46.

Walsh, P., 2005, 'Well-being', in T. Honderich (ed.), The Oxford companion to philosophy, pp. 955-956, Oxford University Press, Oxford.

Wass, A., 2000, Promoting health - the primary health care approach, 2nd edn., Harcourt Australia, Marrickville.

Watt, D., Verma, S. \& Flynn, L., 1998, 'Wellness programs: A review of the evidence', Canadian Medical Association Journal 158(2), 224, viewed 1 March 2001, from http://www-sa. ebsco.com.

Wehmeier, S. (ed.), 2002, Oxford advanced learner's dictionary, Oxford University Press, Oxford.

Westgate, C.E., 1996, 'Spiritual wellness and depression', Journal of Counselling and Development 75(1), 26, viewed 1 March 2001, from http://www-sa.ebsco.com.

Wissing, M.P., 2000, 'Wellness: Construct clarification and a framework for future research and practice', paper presented at the First South African National Wellness Conference, Port Elizabeth, May 2-5.

WHO (World Health Organization), 1986, Young people's health a challenge for society, Technical Report Series 731.

WHO (World Health Organization), 1995, Promoting health through schools. Report of the WHO expert committee on comprehensive education and promotion, WHO, Geneva.

WHO (World Health Organization), 1999, Ottawa Charter for Health Promotion, viewed 17 December 1999, from http:// www.who.dk/policy/ottawa.htm. 